\title{
Analysis of Structural Strength of Modular Floating Pontoon as the Beam of Floating House
}

\author{
Aulia Windyandari, Surya Daud Marulam Tua Sihite, Suharto Suharto and Samuel Samuel \\ Department of Industrial Technology, Vocational School, Diponegoro University, \\ 50275 Semarang, Indonesia \\ auliaw@undip.ac.id, +62-24-76480784
}

\begin{abstract}
The population density and sea flooding cause the reduction in residential land and land area each year. The way to cope with this condition is by creating a floating house. In constructing a building above water, the shape and strength of the beam must be taken into account by considering strong materials and structure constructions such as ferrocement. This study analyzes the structural and connection strength between pontoon ferrocements sized $120 \times 120 \times 100$ with $3 \mathrm{~cm}$ thickness and varied connection among the pontoons. The connection variations include the connection of steel plate with a thickness of $3 \mathrm{~cm}$ and the connection of round bars with a thickness of $4 \mathrm{~cm}$. The modeling is constructed in the software using finite element method and linear static analysis. The analysis of the two types of connections after given the pressure of seawater and house load shows the stress value of steel plate connection is $107 \mathrm{MPa}$ and the stress value of round bars connection is $50 \mathrm{MPa}$. The result shows that both connections are considered safe given the fact that based on the Rules of Indonesian Classification Bureau, the allowed stress for steel plate is $235 \mathrm{MPa}$ and for bars is $255 \mathrm{MPa}$. It means that the structures are safe. The trim pontoon condition resulted from the model creation using Maxsurf and Hydromax Software is trim stern with the height of laden stern is $0.669 \mathrm{~m}$ and the height of laden bow is $0.358 \mathrm{~m}$.
\end{abstract}

$\underline{\text { Key words: } \text { Concrete/ferrocement, finite element, floating house, pontoon, residential, population density }}$

\section{INTRODUCTION}

Indonesia is a country with almost the two third of the territory is ocean. The rest of the territory is Islands full of citizens. Currently, the population density has several impacts including flooding. The increase of water area is caused by the sea flooding in the lowland area. This results in the reduction of residential land and land area each year.

The decrease in land area instigates a solution of using sea area for residential use by building floating house. Currently, several countries have developed floating house including the Netherlands, Canada, countries in Europe and America. In addition, in Indonesia, several cities develop resorts comprising floating house.

In constructing floating house, it is a basic requirement that the beam condition should be secure as in the planning a construction of modular floating pontoon (Wang et al., 2006). Previous studies state that the construction concept of floating house is the concept of lightweight structures aiming to reduce the weight of the floated load (Tran and Kim, 2015). The floater of the floating house depends on the structure integration of floated structure and pontoon (Teoh, 2010).

The planning construction of modular floating pontoon must be able to guarantee a high voltage level structure keeping the structure under the elastic area. Therefore, the construction should have adequate elastic stiffness. Ferrocement is one of the effective materials for the pontoon (Canby, 1969). Ferrocement is a composite material made by giving cement mortar to cane reinforcement through steel (Harsono et al., 1980). Cement mortar functions as the mass and steel wire as the tensile strength and ductility source. Systematically, ferrocement can be referred as a particular form of reinforced concrete in the form of denser concrete. The output of the floating house construction is producing modular floating pontoon with effective and secure structure strength and secure when floating on sea (Kumar, 2005; Rathish, 2010).

Mostly, this study aims to analyze the ideal modular floating pontoon adjusting to the shape of the planned floating house and the structural strength of the modular

Corresponding Author: Aulia Windyandari, Department of Industrial Technology, Vocational School, Diponegoro University, 50275 Semarang, Indonesia, +62-24-76480784, auliaw@undip.ac.id 
floating pontoon. However, this study only focuses on the construction of planned houses with the material used for the floating house beam is ferrocement. In additions, in this study analyses the strength of modular floating pontoon and connection between pontoons and the calculation is using the linear static analysis.

Theoretically, this study calculates the loading value of the entire modular floating pontoon and that of one pontoon and analyzes the value of displacement and maximum stress of the structure of modular floating pontoon.

Linear static analysis: In linear static analysis, the displacements strain, pressure and reaction force were under the influence of the loaded weight. A series of assumptions relating to linear static analysis is deflection, rotation, material properties and boundary condition. Linear static analysis aims to obtain the structural strength of a model in order to investigate the area with the most critical stress due to loading condition (Anonymous, 2013) (Fig. 1).

Finite Element Method (FEM): The basic concept of FEM is solving a problem by dividing the analyzed objects into small finite parts (Jei and Lee, 1988). The small elements are analyzed and the results of the analysis are then assembled to acquire equations for the entire problem (Bae et al., 2016; Phongthanapanich and Dechaumphai, 2009). Finite Element Method (FEM) or the finite element method is one method used to analyze a construction or structure (Zakki et al., 2017; Prabowo et al., 2016). These methods, along with other methods are now widely used in the construction

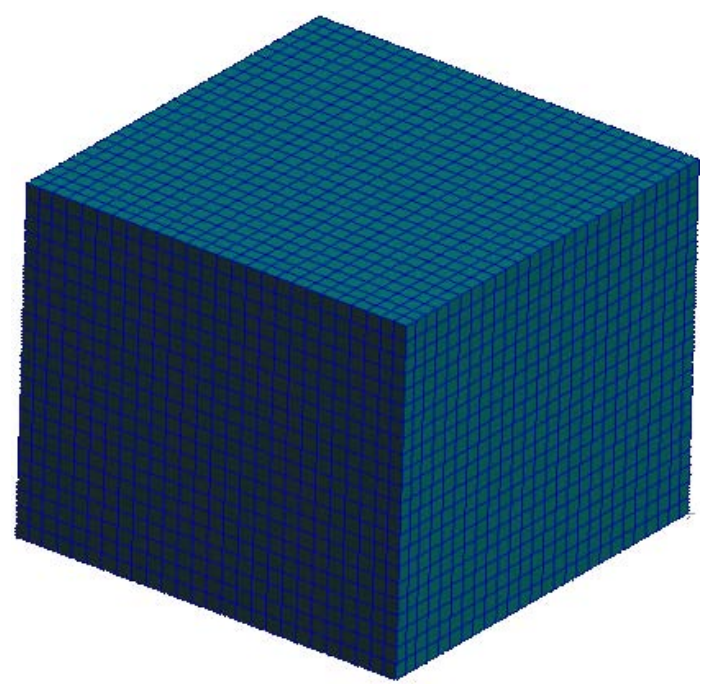

Fig. 1: Floating pontoon of boats and coastal structures and offshore (Altair University, 2012; Prabowo et al., 2017a-d; Yudo et al., 2017; Chrismianto et al., 2015; Zakki et al., 2016). Finite element method is a method used to analyze a construction or structure. This method is widely used in ship construction, beach buildings or offshore. Basic formula:

$$
[\mathrm{K}]\{\mathrm{U}\}=\{\mathrm{F}\}
$$

Structural modeling: The model of floating pontoon structure resembles the shape of cube in Fig. 1.

\section{MATERIALS AND METHODS}

This study used element-based Software MSC Nastran and MSC Patran 2005 to analyze the data. The material specification in this study is.

Pontoon: This study used element-based Software MSC Nastran and MSC Patran 2005 to analyze the data. The material specification in this study is:

- Material: concrete/ferrocement

- Young's modulus: $48 \mathrm{GPa}=4.8 \times 1010 \mathrm{~N} / \mathrm{m}^{2}$

- Density: $2.5 \mathrm{mg} / \mathrm{m}^{3}=2500 \mathrm{~kg} / \mathrm{m}^{3}$

- Shear modulus: $20 \mathrm{GPa}$

- Poisson ratio: 0.20

- Yield stress: $25 \mathrm{MPa}$

- Size: $120 \times 120 \times 100 \mathrm{~cm}$

- Thickness: $3 \mathrm{~cm}$

\section{Steel plate connection (Type A):}

- Size: $20 \times 20 \mathrm{~cm}$

- Thickness: $3 \mathrm{~cm}$

- Material: Steel high strength, grade D

- Young's modulus: $210 \mathrm{GPa}=2.1 \times 1011 \mathrm{~N} / \mathrm{m}^{2}$

- Density: $7.8 \mathrm{mg} / \mathrm{m}^{3}=7800 \mathrm{~kg} / \mathrm{m}^{3}$

- Shear modulus: $76 \mathrm{GPa}$

- Poisson ratio: 0.28

- $\quad$ Yield stress: $235 \mathrm{MPa}$ (Rules BKI) (Fig. 2)

\section{Round bars connection (Type B):}

- Size: 16 and $22.6 \mathrm{~cm}$

- Thickness: $4 \mathrm{~cm}$

- Material: round bars, grade R410

- Young's modulus: $211 \mathrm{GPa}=2.1 \times 10^{11} \mathrm{~N} / \mathrm{m}^{2}$

- Density: $7.874 \mathrm{mg} / \mathrm{m}^{3}=7874 \mathrm{~kg} / \mathrm{m}^{3}$

- Shear modulus: $82 \mathrm{GPa}$

- Poisson ratio: 0.29

- $\quad$ Yield stress: $255 \mathrm{MPa}$ (Fig. 3)

Loading variation: The load on pontoon structure is only from the pressure of seawater and the pressure of both 


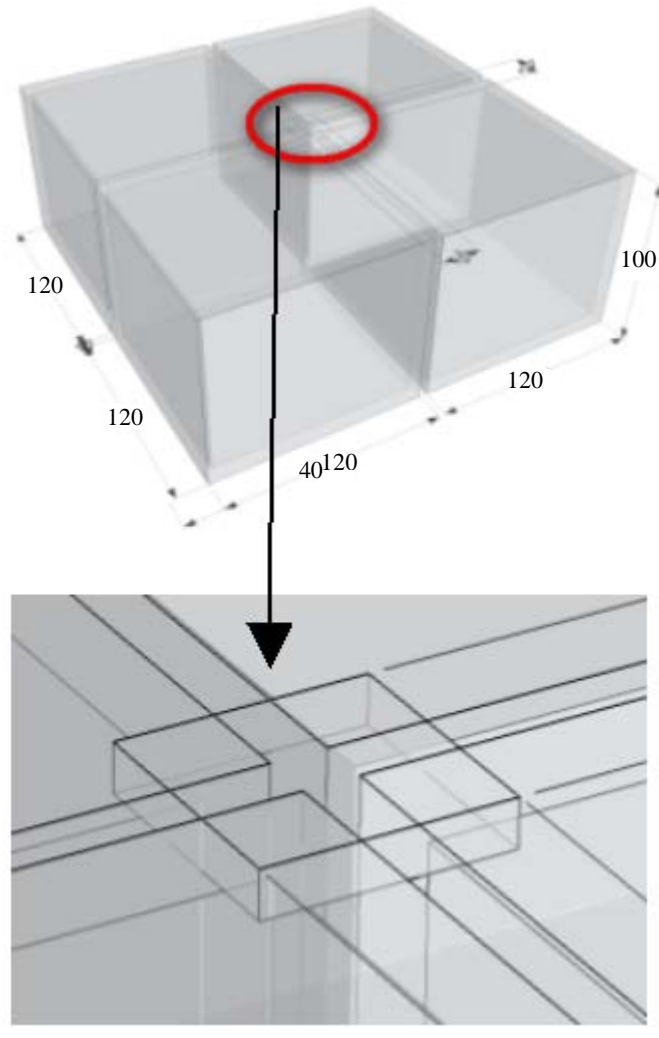

Fig. 2: Steel plate connection

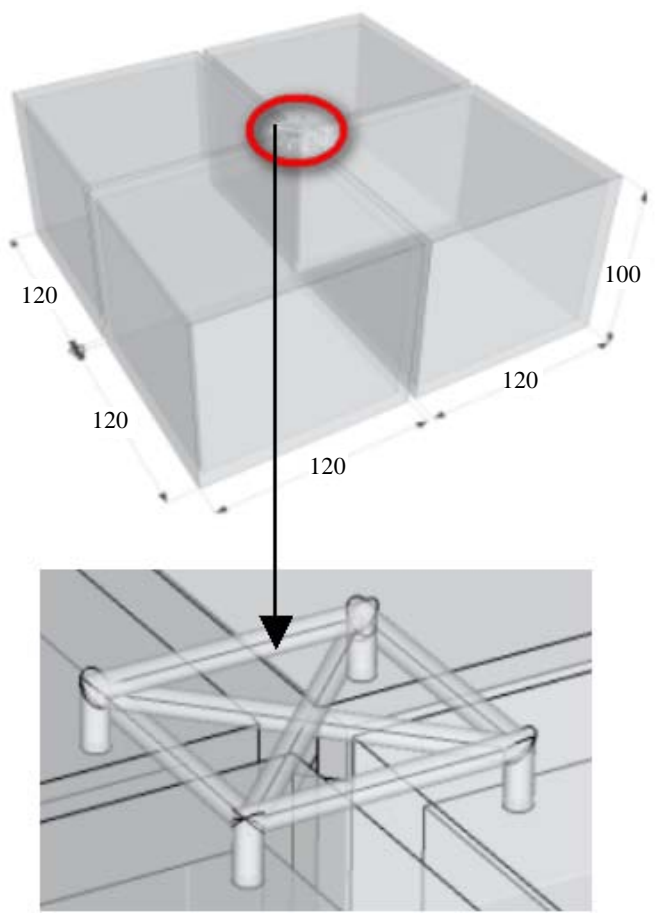

Fig. 3: Round bars connection

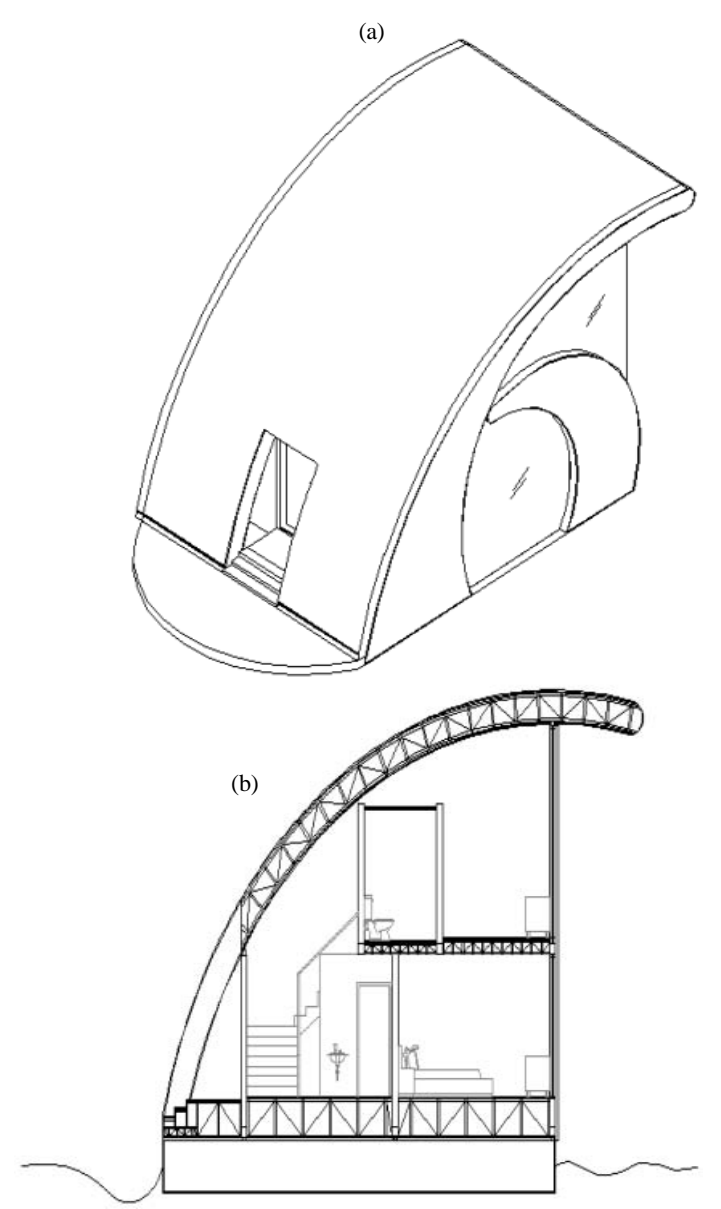

Fig. 4: a, b) Floating house design

seawater and mass/weight of the house. The applied pressure will push the elements existing on the surface of the pontoon (Fig. 4). The pressure calculation using physics approach is:

- $\mathrm{P}=\rho \times \mathbf{g} \times \mathbf{h}$

- P: Pressure $\left(\mathrm{N} / \mathrm{m}^{2}\right)$

- $\rho:$ Density $\left(\mathrm{kg} / \mathrm{m}^{3}\right)$

- $\quad \mathrm{G}$ : Gravitational acceleration $=9.8 \mathrm{~m} / \mathrm{sec}$

- h: Depth of surface (m)

\section{RESULTS AND DISCUSSION}

Type A and B applying the load from seawater with the depth $35 \mathrm{~cm}$ are experiencing pressure:

- $\mathrm{P}=1025 \mathrm{~kg} / \mathrm{m}^{3} \times 9.8 \mathrm{~m} / \mathrm{sec} \times 0.35 \mathrm{~m}$

- $\quad=3515.75 \mathrm{~N} / \mathrm{m}^{2}$ (Pascal)

- $\quad=3.51 \times 10^{3}$ Pascal

Therefore, the maximum load received by the pontoon structure in seawater is $3.51 \times 10^{3} \mathrm{Pascal}$ (Fig. 5). Type A 


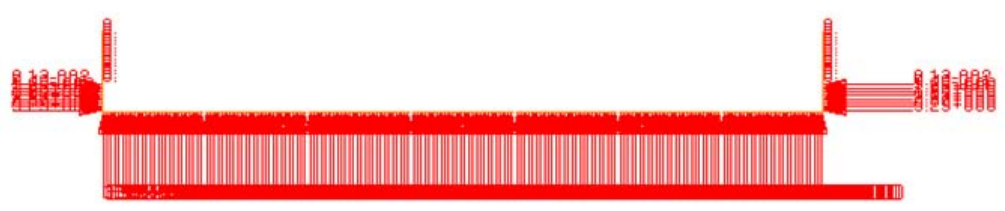

Fig. 5: Seawater pressure

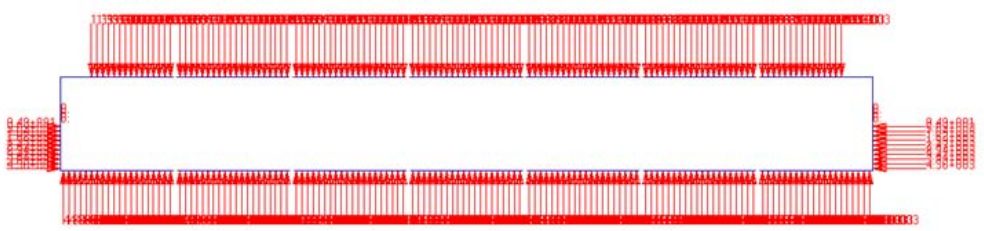

Fig. 6: Seawater and house pressure

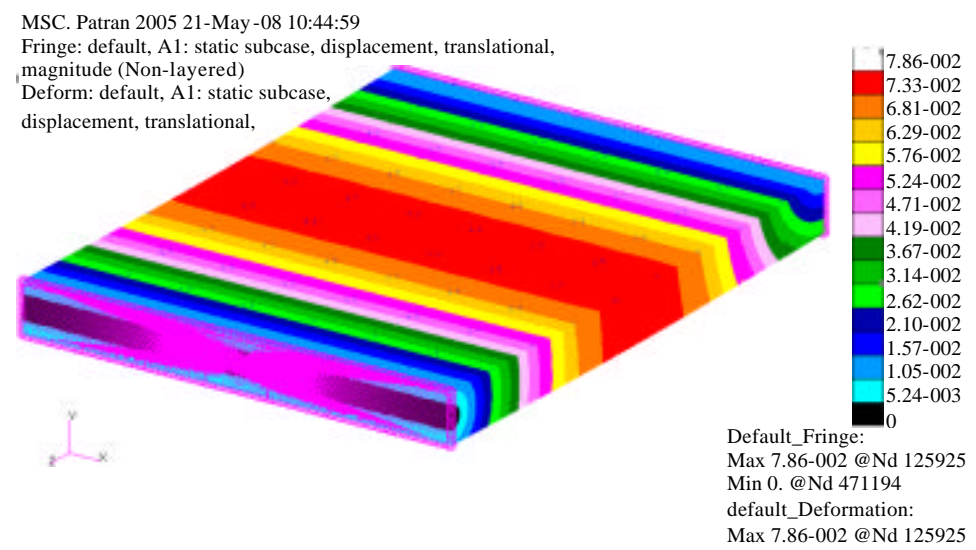

Fig. 7: Deformation type A (seawater pressure)

Table 1: The weight of the house

Mass

House weight

Outfit weight

Altemative weight

Person weight

Freshwater weight

Food weight

Equipment and supplies weight

Total house weight

and $\mathrm{B}$ applying the load from seawater and (Fig. 6) mass/weight of the house with the depth $50 \mathrm{~cm}$ are experiencing pressure:

- $\quad$ Pseawater $=1025 \mathrm{~kg} / \mathrm{m}^{3} \times 9.8 \mathrm{~m} / \mathrm{sec} \times 0.458 \mathrm{~m}$

- $\quad=4600.61 \mathrm{~N} / \mathrm{m}^{2}$ (Pascal)

- $\quad=4.6 \times 10^{3}$ Pascal

To calculate the pressure from the house sized $10 \times 8 \mathrm{~m}$, measure the mass/weight of the house and divide with the volume of the house (Table 1). The pressure calculation using physics approach is:

- $\mathrm{P}=\mathrm{F} / \mathrm{A}$

- $=(13665.17 \times 9.8) / 39.41$
$9,975.89$

32

101.28

320

1,200

2000

$13,665.17$
- $\quad=3398.09 \mathrm{~N} / \mathrm{m}^{2}$ (Pascal)

- $\quad=3.39 \times 10^{2}$ Pascal

Type A (seawater pressure): In this condition, deformation occurred with the largest displacement value of $7.86 \times 10^{-2} \mathrm{~m}$ or $7.86 \mathrm{~cm}$ at node 125,925 and the smallest displacement value $0 \mathrm{~m}$ at node 471,194 . The maximum stress occurred with the value $1.27 \times 10^{-8}$ Pascal at node 904,661 and the smallest stress value is $5.90 \times 10^{-3}$ at node 9,490. The maximum stress was in the central part of the floating pontoon connection. This condition occurred because the central part of modular floating pontoon was located at the farthest from the pedestal flops given to the model (Fig. 7 and 8).

Type A (seawater and house pressure): In this condition, deformation occurred with the largest displacement value of $9.98 \times 10^{-2} \mathrm{~m}$ or $9.98 \mathrm{~cm}$ at node 129,510 and the smallest displacement value $0 \mathrm{~m}$ at node 471194. The maximum stress occurred with the value $2.03 \times 10^{-8}$ Pascal at node 904,823 and the smallest stress value is $6.67 \times 10^{-3}$ at node 999,506 (Fig. 9 and 10 ). The 
(a)

MSC. Patran 2005 21-May-08 10:48:04

Fringe: default, A1: static subcase, stress tensor, von Mises, At Z

Deform: default, A1: static subcase,

displacement, translational

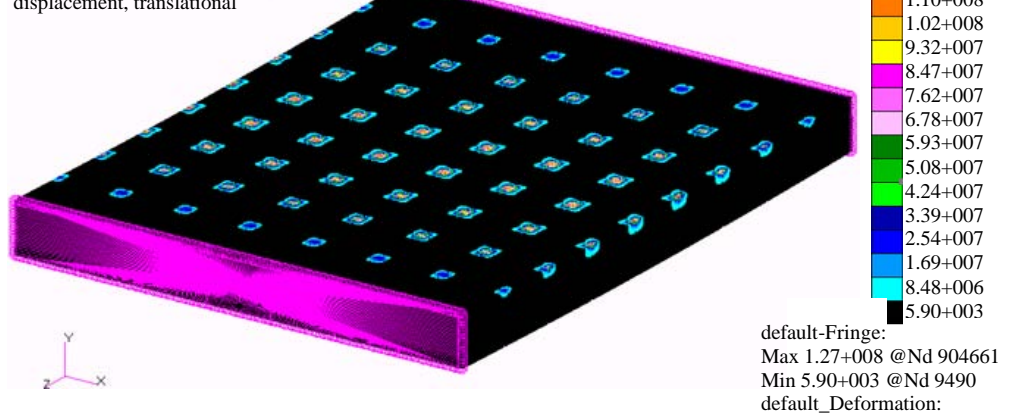

Max 7.86-002@Nd 12592

Fig. 8: a, b) Stress tipe A (seawater pressure)

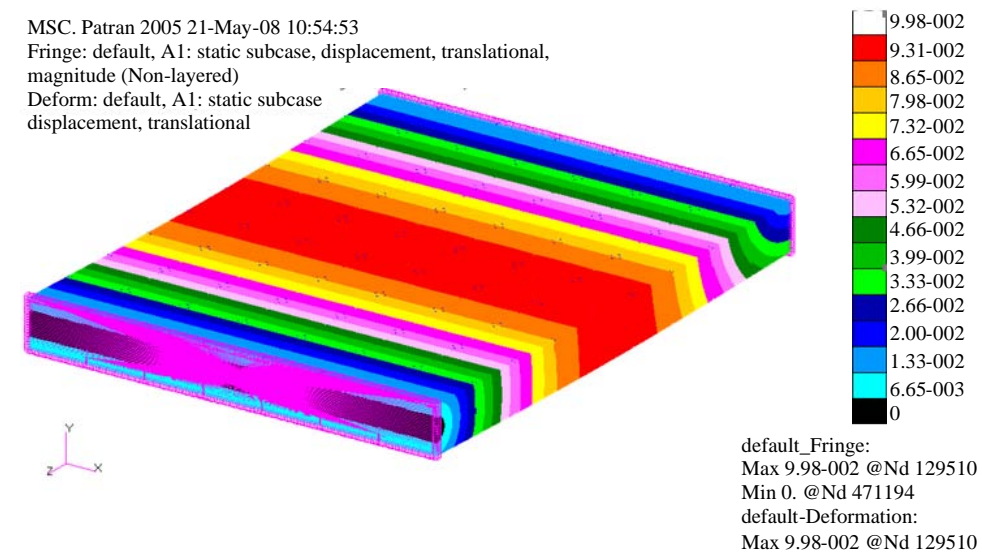

Fig. 9: Deformation type A (seawater and house pressure)

(a)

MSC. Patran 2005 21-May-08 10:59:31

Fringe: default, A2: static subcase, stress tensor, von Mises, At Z2

Deform: default, A2: static subcase,

displacement, translational

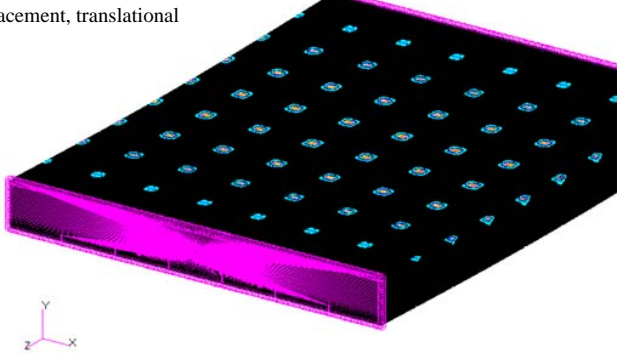

Max2.03+008@Nd 904823

Max 2.03+008@Nd 904823

default-Deformation:

Max 9.98-002@Nd 129510

(b)

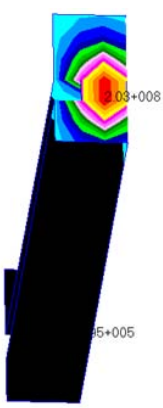

(b)

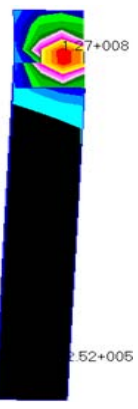




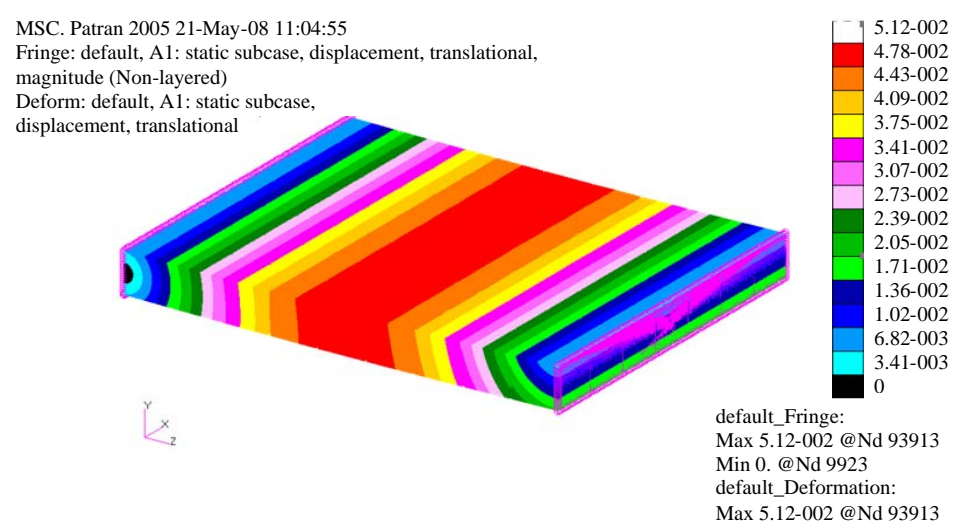

Fig. 11: Deformation type B (seawater pressure)

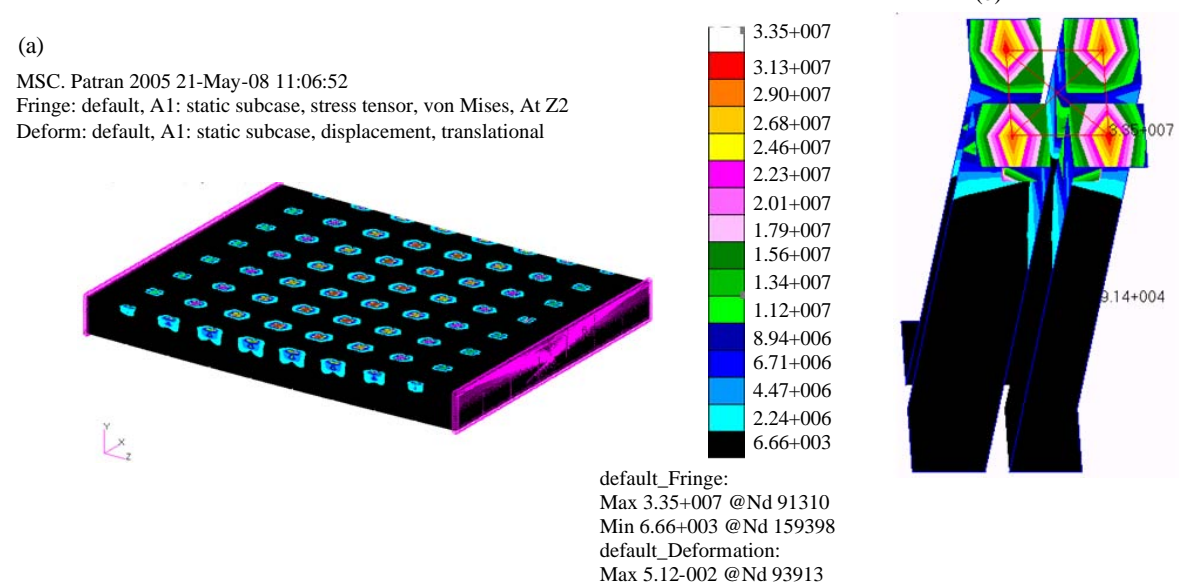

Fig. 12: a, b) Type B (seawater pressure)

Type B (seawater pressure): In this condition, deformation occurred with the largest displacement value of $5.12 \times 10^{-2} \mathrm{~m}$ or $5.12 \mathrm{~cm}$ at node 93913 and the smallest displacement value $0 \mathrm{~m}$ at node 9923 . The maximum stress occurred with the value $3.35 \times 10^{-7}$ Pascal at node 91,310 and the smallest stress value is $6.66 \times 10^{-3}$ at node 159,398 . The maximum stress was in the central part of the floating pontoon connection. This condition occurred because the central part of modular floating pontoon was located at the farthest from the pedestal flops given to the model. In this condition, the stress/tension intensifies because the modular floating pontoon received pressure from above, the house (Fig. 11 and 12).

Type B (seawater and house pressure): In this condition, deformation occurred with the largest displacement value of $7.64 \times 10^{-2} \mathrm{~m}$ or $7.64 \mathrm{~cm}$ at node 93,913 and the smallest displacement value $0 \mathrm{~m}$ at node 9,923 . The maximum stress occurred with the value $5.00 \times 10^{-7}$ Pascal at node 91,310 and the smallest stress value is $1.69 \times 10^{-4}$ at node 162,002 .
Table 2: Correction for each condition

\begin{tabular}{llccl}
$\begin{array}{l}\text { Connection } \\
\text { types }\end{array}$ & Pressure & $\begin{array}{c}\text { Max stress } \\
(\mathrm{Mpa})\end{array}$ & $\begin{array}{c}\text { Allowed stress } \\
(\mathrm{MPa})\end{array}$ & Status \\
\hline Steel plate & Seawater & 107 & 235 & Eligible \\
Steel plate & Seawater and house & 203 & 235 & Eligible \\
Round bars & Seawater & 33.5 & 255 & Eligible \\
Round bars & Seawater and house & 50 & 255 & Eligible \\
\hline
\end{tabular}

The maximum stress was in the central part of the floating pontoon connection. This condition occurred because the central part of modular floating pontoon was located at the farthest from the pedestal flops given to the model. In this condition, the stress/tension intensifies because the modular floating pontoon received pressure from above, the house (Fig. 13-15). The results showed that all the stress/maximum tension occurring in each condition or circumstance met the criteria of allowed stress of each material property corresponding to the Rules of Indonesian Classification Bureau Volume V (Table 2 and 3).

Trim condition of modular floating pontoon: Based on the load distribution and the center of gravity on modular 


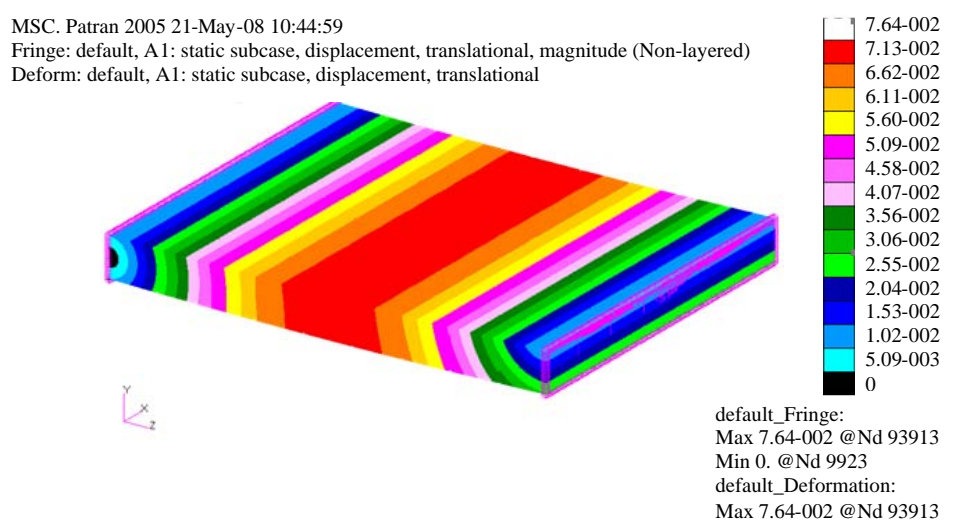

Fig. 13: Deformation type B (seawater and house pressure)

(a)

MSC. Patran 2005 21-May-08 11:11:52

Fringe: default, A1: static subcase, stress tensor, von Mises, At 22

Deform: default, A1: static subcase, displacement, translational

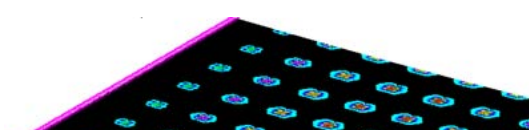

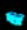

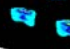

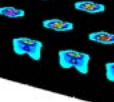
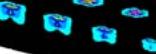

$L_{2}^{x}$

Max 5.00+007@Nd 91310

Min 1.69+004@Nd 162002

default_Deformation:

Max 7.646-002@Nd 93913

(b)

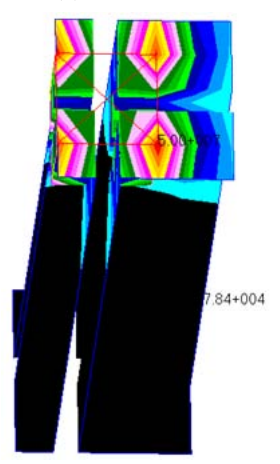

Fig. 14: a, b) Stress type B (seawater and house pressure)

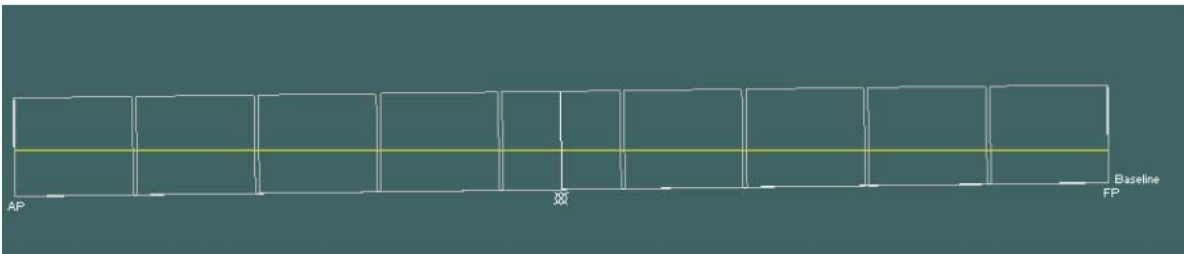

Fig. 15: Equilibrium results of modular floating pontoon in $\mathrm{H}$ ydromax Software

Table 3: Equilibrium results of modular floating pontoon

\begin{tabular}{lr}
\hline Variables & Values \\
\hline Draft Amidsh (m) & 0.513 \\
Displacement tonne & 38.870 \\
Heel to starboard degrees & 0.000 \\
Draft at FP (m) & 0.358 \\
Draft at AP (m) & 0.669 \\
Draft at LCF (m) & 0.513 \\
Trim (+ve by stern) (m) & 0.311 \\
WL Length $(\mathrm{m})$ & 11.124 \\
WL Beam $(\mathrm{m})$ & 6.640 \\
Wetted area $\left(\mathrm{m}^{2}\right)$ & 92.074 \\
Waterpl. area $\left(\mathrm{m}^{2}\right)$ & 73.866 \\
\hline
\end{tabular}


Table 3: Continue

\begin{tabular}{lr}
\hline Variables & Values \\
\hline Prismatic coeff. & 0.768 \\
Block coeff. & 0.768 \\
Midship area coeff. & 1.000 \\
Waterpl. area coeff. & 1.000 \\
LCB from Amidsh. (+ve fwd) (m) & -0.561 \\
LCF from Amidsh. (+ve fwd) (m) & 0.000 \\
KB (m) & 0.265 \\
KG fluid (m) & 1.959 \\
BMt (m) & 7.159 \\
BML (m) & 20.094 \\
GMt corrected (m) & 5.464 \\
GML corrected (m) & 18.398 \\
KMt (m) & 7.423 \\
KML (m) & 20.358 \\
Immersion (TPc) (tonne/cm) & 0.757 \\
MTc tonne. (m) & 0.643 \\
RM at $1^{\circ}=$ Gmt.Disp.sin (1) (tonne.m) & 3.706 \\
Max deck inclination (deg) & 1.6 .00 \\
Trim angle (+ve by stern) (deg) & 1.6 .00 \\
Draft Amidsh. (m) & 0.513 \\
\hline
\end{tabular}

floating pontoon, the running analysis resulted the stern trim condition with the value of the height of laden stern $0.669 \mathrm{~m}$ and the height of laden bow $0.358 \mathrm{~m}$ (Table 3).

\section{CONCLUSION}

The load of the house received by modular floating pontoon can be classified as follows: the height of laden of modular floating pontoon without the house load is $35 \mathrm{~cm}$. The height of laden of the entire modular floating pontoon (63 pontoons) receiving $13665.17 \mathrm{~kg}$ house load is $45.8 \mathrm{~cm}$. For each increment load of $60 \mathrm{~kg}$, the height of laden increase by $3 \mathrm{~cm}$, meaning that each pontoon received $216.9 \mathrm{~kg}$ load. The result shows the stern trim condition with the value of the height of laden stern $0.669 \mathrm{~m}$ and the height of laden bow $0.358 \mathrm{~m}$.

The analysis of the two types of connections (type A and B) given the pressure of seawater and house show that type A (seawater pressure) experiencing stress $107 \mathrm{MPa}$. Type A (seawater and house pressure) experiencing stress $203 \mathrm{MPa}$. Type B (seawater pressure) experiencing stress $33.5 \mathrm{MPa}$. Type $\mathrm{B}$ (seawater and house pressure) experiencing stress $50 \mathrm{MPa}$. Finally, all stresses are considered secure as they do not exceed the allowed stress established by Rules Indonesia Classification Bureau Volume V.

\section{ACKNOWLEDGEMENT}

This research supported by Research Program supported by the Diponegoro University. We would like to announce our sincere thank for Dwi Ariyani, Mirra Fatharani and Winda Astuti for their valuable editing assistance.

\section{REFERENCES}

Altair University, 2012. Practical Aspects of Finite Element Simulation: A Study Guide. Altair University, Troy, Michigan,.

Anonymous, 2013. Linear static analysis. Altair Engineering, Bengaluru, India.

Bae, D.M., A.R. Prabowo, B. Cao, A.F. Zakki and G.D. Haryadi, 2016. Study on collision between two ships using selected parameters in collision simulation. J. Mar. Sci. Appl., 15: 63-72.

Canby, C.D., 1969. Ferro-cement with particular reference to marine applications. Ph.D Thesis, University of Michigan, Ann Arbor, Michigan.

Chrismianto, D., A.F. Zakki, B. Arswendo and D.J. Kim, 2015. Development of cubic Bezier curve and curve-plane intersection method for parametric submarine hull form design to optimize hull resistance using CFD. J. Mar. Sci. Appl., 14: 399-405.

Harsono, W., F. Harahap, A. Djausal, J.B. Manga and A. Hayat et al., 1980. Ferrocement technology in Indonesia. Master Thesis, Institut Teknologi Bandung, Bandung, Indonesia.

Jei, Y.G. and C.W. Lee, 1988. Finite element model of asymmetrical rotor-bearing systems. KSME. J., 2: 116-124.

Kumar, A., 2005. Ferrocement box sections-viable option for floors and roof of multi-storeyed buildings. Asian J. Civ. Eng., 6: 569-582.

Phongthanapanich, S. and P. Dechaumphai, 2009. Combined finite volume and finite element method for convection-diffusion-reaction equation. J. Mech. Sci. Technol., 23: 790-801. 
Prabowo, A.R., B. Cao, D.M. Bae, S.Y. Bae and A.F. Zakki et al., 2017d. Structural analysis of the double bottom structure during ship grounding by finite element approach. Lat. Am. J. Solids Struct., 14: 1106-1123.

Prabowo, A.R., D.M. Bae, J.M. Sohn and A.F. Zakki, 2016. Evaluating the parameter influence in the event of a ship collision based on the finite element approach. Intl. J. Technol., 7: 592-602.

Prabowo, A.R., D.M. Bae, J.M. Sohn, A.F. Zakki and B. Cao et al., 2017a. Analysis of structural behavior during collision event accounting for bow and side structure interaction. Theor. Appl. Mech. Lett., 7: 6-12.

Prabowo, A.R., D.M. Bae, J.M. Sohn, A.F. Zakki and B. Cao et al., 2017c. Effects of the rebounding of a striking ship on structural crashworthiness during ship-ship collision. Thin Walled Struct., 115: 255-259.

Prabowo, A.R., D.M. Bae, J.M. Sohn, A.F. Zakki and B. Cao, 2017b. Rapid prediction of damage on a struck ship accounting for side impact scenario models. Open Eng., 7: 91-99.

Rathish, K.P., 2010. High performance super plasticized silica fume mortars for ferrocement works. Facta Univ. Ser. Archit. Civ. Eng., 8: 129-134.
Teoh, B.T., 2010. Floating house to tackle problems during flash flood. Ph.D Thesis, Universiti Teknologi Malaysia, Johor Bahru, Malaysia.

Tran, T.T. and D.H. Kim, 2015. The aerodynamic interference effects of a floating offshore wind turbine experiencing platform pitching and yawing motions. J. Mech. Sci. Technol., 29: 549-561.

Wang, C., S.X. Fu, N. Li, W.C. Cui and Z.M. Lin, 2006. Dynamic analysis of a pontoon-separated floating bridge subjected to a moving load. China Ocean Eng., 20: 419-430.

Yudo, H., A. Windyandari and A.F. Zakki, 2017. Numerical investigation of the buckling strength behavior of ring stiffened submarine pressure hull. Intl. J. Civ. Eng. Technol., 8: 408-415.

Zakki, A.F., A. Windyandari and D.M. Bae, 2016. The development of new type free-fall lifeboat using fluid structure interaction analysis. J. Mar. Sci. Technol., 24: $575-580$.

Zakki, A.F., D.M. Bae, S. Susilo, E.A. Sipayung and Suharto, 2017. Structure design and characteristic analysis of buckling strength on swedge frame pressure hull with finite element analysis. ARPN. J. Eng. Appl. Sci., 12: 821-833. 